\title{
Successful implementation of corporate strategy in the context of digital transformation
}

\author{
Daria Shalina, Natalia Stepanova, and Pavel Bochkov** \\ Ural Federal University (UrFU), Mira, 19, Ekaterinburg, Russia
}

\begin{abstract}
In our research, we cover the problem of strategic planning in the modern period within a separate organization. Long-term fixed strategies are losing their relevance in an unstable, constantly modernizing world. During the CAVID-19 crisis, companies realized the need for changes in the direction of digital transformation. Features of digitalization cause the need to form a new strategy of the organization, the implementation of which requires certain actions. The purpose of the study was to justify these actions. After studying the material that makes up the new corporate strategy, we identified the requirements for its implementation with maximum results. The research substantiates the concepts of corporate strategy, corporate culture, digitalization and its features. The results of the research will become recommendations for modern companies in the formation and implementation of corporate strategy.
\end{abstract}

\section{Introduction}

In the modern world, the role of information data is rapidly increasing [1]. Every year, digitalization is transformed from a simple way to improve performance to a real boost to the development of the global community [2]. Along with this, people's activities are also being transformed. We are beginning to introduce elements of digitalization in various areas of activity everywhere in order to increase efficiency.

The trigger for digitalization in 2020 was the COVID-19 crisis. The pandemic was the reason for the dynamic transition of organizations to the digital space, which is still incomprehensible and new to us today. Some companies have moved their operations online in the shortest possible time. Now their interaction with external stakeholders is carried out through digital technologies. So digital technologies have become a Central element of society [3].

However, there are companies that have not been able to cope with the digital transformation. The main reason for this was their unstable position in the market, which is provided by the internal organization of the company, namely the corporate culture [4]. Employees were simply not ready to adapt quickly and flexibly to the new conditions of existence due to the optimized corporate culture.

\footnotetext{
* Corresponding author: bochkov05@mail.ru
} 


\subsection{Relevance and practical significance}

Before the COVID-19 crisis, digitalization was an element of the future for many. However, under unfavorable epidemiological conditions, the situation has changed. The company's success over the years is ensured by its ability to adapt dynamically to changes. The willingness to show flexibility in the process of transformation is becoming more relevant and necessary quality every year [5].

Companies now face the challenge of maintaining sustainability in an unstable environment. They need to properly implement technologies that are relevant to their business so that they maintain close relationships with employees, customers, and suppliers. And the better they do it, the less losses companies will suffer during the crisis and the more success they will expect after it [3].

At the heart of any company is a strategy that is set for several years. Attempts to adapt to the external situation may seriously contradict the company's plan. Hence, there is an urgent need for new requirements for the formation and implementation of the company's strategy. Knowing these needs, modern organizations can change their vision for strategic planning and will consider the new conditions of existence.

\subsection{Goals and objectives}

The purpose of our research is to compile and justify a list of requirements for the formation and implementation of a corporate strategy in the context of digital transformation.

To achieve this goal, the following tasks were identified:

- Study the corporate strategy of a modern enterprise;

- Identify the main components of the corporate strategy;

- $\quad$ Analyze the most significant areas of development;

- Identify and justify requirements when forming and implementing a corporate strategy.

In the study, the digitalization is estimated as a positive factor of influence on modern company. However, negative features are also highlighted and ways to prevent them are suggested.

\subsection{Scientific novelty}

Determination of the need to transform existing models of corporate strategies in the new economic conditions. Identify several factors that need to be considered when planning and organizing a corporate strategy. Their justification. Finally, the introduction of new strategic trends formed in the context of digitalization and the Covid-19 crisis into the corporate strategic planning of modern organizations. In this way, we suggest that businesses change their traditional understanding of corporate strategy to a new digital mindset.

\section{Materials and methods}

\subsection{Effectiveness of the corporate strategy}

The company's strategy is an important and integral element of any modern company. Regardless of size or type, companies try to achieve the desired state in the future. And this is the achievement of the set goal of the state of development of the company. The most 
important strategy is corporate. This is a General strategy for the development of the entire organization and all its elements. The corporate strategy contains the main guidelines and development directions that the company must adhere to in order to quickly and effectively achieve the desired result [6].

In today's ever-changing environment, companies must take a detailed approach to strategic planning. One of the factors of a well-designed strategy is to optimize the use of resources. For the most effective activity, managers must rationally allocate resources among the components of the business. Hence, another important factor is ensuring the company's stable position despite external unstable conditions $[6,7]$.

The effectiveness of the corporate strategy is the result of a correct assessment of the conditions and opportunities for the company's development, which include current trends and development directions [7]. The most significant trend is digitalization. Today, most companies need to improve production and economic processes, as it is necessary to quickly and accurately meet the new needs of consumers. Therefore, information and communication technologies are being introduced that can quickly and accurately determine the needs and interests of consumers, as well as improve the company's efficiency and corporate culture [2].

\subsection{Corporate culture as a component of corporate strategy}

Corporate culture is a set of internal elements of the company, on the organization of which the work of the entire company depends. It creates a unique image of the entire company, which distinguishes it from others. Therefore, the success and effectiveness of corporate strategy implementation depends on corporate culture $[4,8]$.

Corporate culture contains six main elements: corporate identity, mission, values, traditions, rituals, and corporate mythology. Each of them is aimed at improving the quality of work of the company's employees (see Table 1).

Table 1. Main elements of corporate culture [4]

\begin{tabular}{|l|l|}
\hline \multicolumn{1}{|c|}{ Element } & \multicolumn{1}{c|}{ Description } \\
\hline $\begin{array}{l}\text { Corporate } \\
\text { identity }\end{array}$ & $\begin{array}{l}\text { It involves combining employees based on common principles (from clothing style } \\
\text { to documentation) }\end{array}$ \\
\hline $\begin{array}{l}\text { Company } \\
\text { mission }\end{array}$ & $\begin{array}{l}\text { It will convey the meaning of the company's functioning and reflect the internal } \\
\text { direction of its development }\end{array}$ \\
\hline $\begin{array}{l}\text { Corporate } \\
\text { value }\end{array}$ & $\begin{array}{l}\text { They form the desired behavior of employees. The management of a modern } \\
\text { company focuses on such a list of values for its employees that they are motivated } \\
\text { to perform work with maximum results }\end{array}$ \\
\hline $\begin{array}{l}\text { Traditions } \\
\text { and rituals }\end{array}$ & $\begin{array}{l}\text { They are needed to unite the team. With the help of these elements strengthens the } \\
\text { current rules in the company. They ensure the company's sustainability in a time of } \\
\text { changing conditions and innovation }\end{array}$ \\
\hline $\begin{array}{l}\text { Corporate } \\
\text { mythology }\end{array}$ & $\begin{array}{l}\text { Corporate mythology helps to convey to employees the meaning of all elements of } \\
\text { the company's mission. It is the Foundation of the corporate culture. Employees } \\
\text { perceive myths as the main postulates of the company's development }\end{array}$ \\
\hline
\end{tabular}

Elements of corporate culture provide modern organizations with a stable position in the market. The company responds to changes by adapting its corporate culture to new operating conditions. Employees themselves must be prepared for changes, constantly update their knowledge and analyze market changes [8].

However, digitalization, by introducing its own templates, destroys the uniqueness of the company. It is lost against the background of competitors. In this regard, along with the modernization of the entire company's processes, we should not forget about improving the corporate culture. 
Internal employee interactions affect customer loyalty. If a friendly family atmosphere prevails in the company, then customers will feel comfortable. To create such interaction, it is necessary to increase the trust of employees in each other, since cohesion and teamwork are the key to successful operation of the enterprise. The corporate culture should contain a positive attitude, trust, responsibility, creativity and cohesive interaction [9].

Modern companies are forced to adapt their business model to new conditions, and therefore modernize their corporate strategy, including the development of corporate culture and elements of digitalization $[2,8]$.

\subsection{Digitalization of the company}

\subsubsection{General characteristics of digitalization}

The concept of "digitalization" has many formulations. First of all, digitalization is technologies that process large amounts of data by converting information into digital form or into digital data sets. Therefore, costs are reduced, and new opportunities appear. In this context, we are talking about digitalization of a separate element of the company's activities $[1,2,5]$.

Digitalization covers production, business, science and the social sphere in a broader concept, where digitalization is interpreted as a modern direction of development of the world economy and society. And this is already helping to increase the efficiency of the economy and improve the quality of life.

Global digitalization involves effective use of its results by specialists and ordinary people. Therefore, there is a need for skills in working with digital information [2].

In General, digitalization is a tool in the form of technologies that people can use to optimize and improve their activities.

\subsubsection{Advantages of having digitalization in a modern company}

The spread of digitalization is characterized by high rates. This is due to a large range of positive characteristics of digitalization, which help to improve the process of activity and its result [2].

Digitalization contributes to overall improvement, but in different areas of activity, this improvement can be presented in different ways. So, at the level of an individual company, there are certain features of improvement through digitalization (see Table 2) $[1,5]$.

Table 2. Digital features of companies. Sources $[1,2,5]$.

\begin{tabular}{|l|l|l|}
\hline \multicolumn{1}{|c|}{ Feature } & \multicolumn{1}{|c|}{ Description } & \multicolumn{1}{c|}{ Practical using } \\
\hline $\begin{array}{l}\text { The creation } \\
\text { of new }\end{array}$ & $\begin{array}{l}\text { The Internet space gives its users } \\
\text { Intimited opportunities. Each } \\
\text { technologies } \\
\text { company finds appropriate tools in } \\
\text { it and uses them to improve internal } \\
\text { processes [1,5] }\end{array}$ & $\begin{array}{l}\text { Exclusion of intermediaries. } \\
\text { Manufacturers can create a website where } \\
\text { they will communicate directly with their } \\
\text { potential customers. The sales process } \\
\text { will speed up [2] }\end{array}$ \\
\hline $\begin{array}{l}\text { The use of the } \\
\text { corporate } \\
\text { platform }\end{array}$ & $\begin{array}{l}\text { At the company level, you can use } \\
\text { your own platform, technology } \\
\text { environment, where certain tasks } \\
\text { can be performed. This accelerates } \\
\text { business processes and reduces } \\
\text { communication time [2] }\end{array}$ & $\begin{array}{l}\text { Or cost optimization. The Internet } \\
\text { provides a large amount of information, } \\
\text { you can use it to promote products, sign } \\
\text { contracts, and much more. Free or saved } \\
\text { time can be devoted to the development } \\
\text { of personal and professional skills of } \\
\text { employees [1,2] }\end{array}$ \\
\hline
\end{tabular}


Continuation of Table 2. Digital features of companies. Sources $[1,2,5]$.

\begin{tabular}{|l|l|l|}
\hline $\begin{array}{l}\text { Quick } \\
\text { response to } \\
\text { market } \\
\text { changes }\end{array}$ & $\begin{array}{l}\text { In modern conditions, successful } \\
\text { companies respond quickly and } \\
\text { flexibly to changes. Thanks to } \\
\text { digitalization, large amounts of } \\
\text { information are automatically } \\
\text { processed and synchronized [2] }\end{array}$ & $\begin{array}{l}\text { Employees can make changes to projects } \\
\text { without notifying other employees due to } \\
\text { automatic updates, distribute information } \\
\text { without losing its accuracy and clarity }\end{array}$ \\
\hline $\begin{array}{l}\text { Strengthening } \\
\text { interdisciplina } \\
\text { ry } \\
\text { collaboration }\end{array}$ & $\begin{array}{l}\text { Digitalization has a strong impact } \\
\text { on the company's internal system. } \\
\text { Based on digital technologies, all } \\
\text { employees are United by one idea } \\
\text { and are ready to implement the } \\
\text { company's strategy together [5] }\end{array}$ & $\begin{array}{l}\text { The needs of consumers are constantly } \\
\text { updated, which requires considerable } \\
\text { time to analyze and create a new product } \\
\text { or service. Companies through } \\
\text { digitalization better understand their } \\
\text { potential customers and can accurately } \\
\text { meet their existing and new needs [2] }\end{array}$ \\
\hline
\end{tabular}

Thus, the use of such a tool as digitalization increases the productivity and efficiency of the company. Internal processes are almost completely digitized. At the same time, digitalization technologies help to predict changes with greater accuracy and build the necessary strategies for the future successful development of the company $[1,2,5]$.

\subsubsection{Disadvantages of digitalization}

Digitalization helps to improve the performance of modern companies and solve many problems with optimizing the company's resources and sustainability. But along with the positive effect of digital technologies, other problems may appear in the company. For example, indifference to living people appears and increases, people's dependence on technology increases, their individuality disappears, everyone is like each other, new technical opportunities for violating privacy appear, and so on $[1,2]$.

Negative features of digital technologies contribute to the emergence of complex slowing down situations. Distrust of new technologies can slow down the introduction of digitalization elements. Natural rejection of the new occurs for reasons of lack of necessary knowledge and lack of preparation. Even the most advanced company will not be able to work effectively based on digital transformation without appropriate training of employees and jobs $[2,3,10]$.

Elements of digitalization provide many positive opportunities that can lead to misperceptions of new technologies. Digitalization is just a tool for achieving results faster and more effectively. When basing its activities and corporate strategy on it, the company should remember that it uses digital technologies to its advantage, and not Vice versa [2, 5].

When making corporate decisions, management is based on experience, intelligence, and intuition. The person decides in which direction the company will move, what results need to be achieved and what tools will be used. It is necessary to differentiate the areas of human activity and use digitalization technologies in the company to prevent corporate disputes and problems $[1,10]$.

Thus, digitalization is changing social society and modern companies. It is only possible to use the digitalization tool to increase the company's efficiency if this phenomenon is properly understood and perceived. It is necessary to master the skills and knowledge of digital technologies $[1,2]$.

\section{Results and discussion}

Before the introduction of digital technologies, the company has potential risks that can lead it out of the state of sustainability and lead to a decrease in efficiency. With the 
introduction of digitalization, new additional risks appear. The company's lack of preparation can lead to the implementation of risks that were previously suppressed, and new risks [10]. The problems that have arisen due to the introduction of digitalization elements make companies perceive this phenomenon as a complex tool that requires preparatory operations.

First of all, the company must clearly understand its current situation and potential problems. It requires a clear analysis of the market structure, the organization's capabilities at this level of development, as well as an analysis of the prospects for implementing a particular technology. It will be able to really assess the opportunities from the introduction of digital technologies and will use them as tools for solving these problems. This is where the digital corporate strategy of a modern company begins to take shape.

We found out that digitalization cannot exist separately from a person, so the second preparatory action is to analyze and improve the abilities of employees. Digitalization requires certain knowledge that is constantly changing and updated. The same concept should be followed when training employees. You should constantly conduct new trainings or courses.

Digitalization creates a new intellectual potential of the company based on the corporate culture. A new trend of strategic planning is emerging, which makes the company much more efficient even when working remotely (see Figure 1).

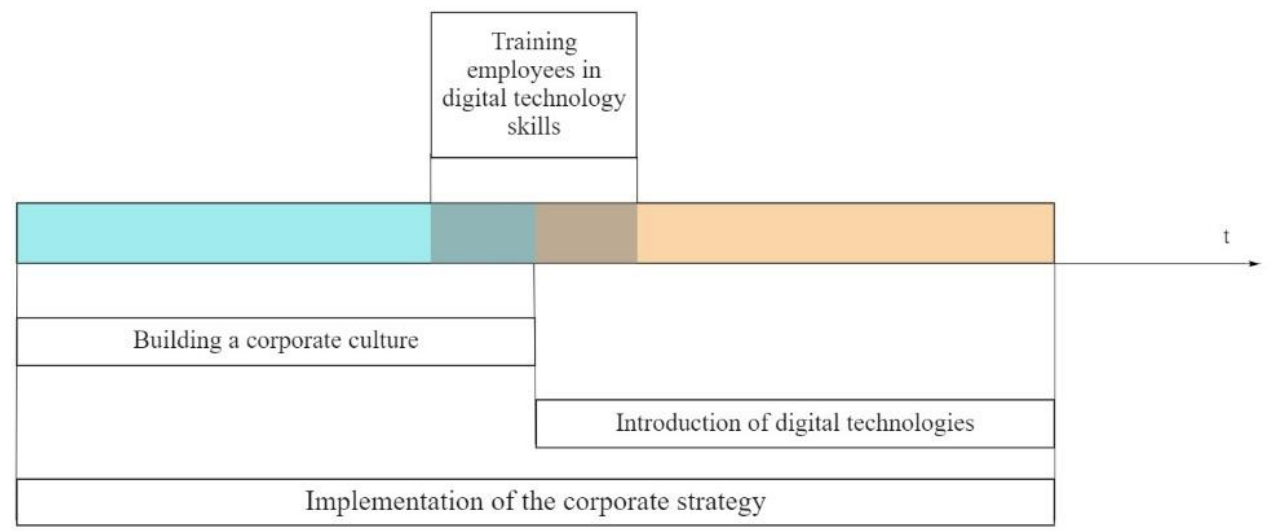

Fig. 1. The trend of improving the intellectual potential for the implementation of corporate strategy.

Digitalization requires skilled workers. The management of a successful modern company is aware that employees need skills and knowledge to work with digital technologies. And at the same time, human activity becomes valuable, important and unique.

This makes strategic planning more detailed, operational, and flexible. The combination of the current modern environment, corporate culture and digital technologies defines new strategic directions for the development of enterprises[11, 12]:

1. Focus on the people. Along with digitalization, the value of human labor is growing. People provide human potential and use digital tools to optimize their activities.

2. Independence from location. The digital world does not require linking to a specific place of work. However, it requires appropriate technologies to function effectively.

3. Stable service delivery. The ability to adapt quickly will ensure the organization's stable position in the industry. It is relevant in the modern world with unstable conditions.

Each of these areas can be divided into strategic technological trends of the present and future, which are presented in Table 3. 
Table 3. Strategic technology trends.

\begin{tabular}{|c|c|c|}
\hline Trend & Description & Reason \\
\hline \multicolumn{3}{|c|}{ Focus on people } \\
\hline $\begin{array}{l}\text { Internet } \\
\text { behavior }\end{array}$ & $\begin{array}{l}\text { Chipping employees through } \\
\text { gadgets or sensor implants }\end{array}$ & $\begin{array}{l}\text { Tracking people's behavior through a } \\
\text { digital footprint in order to influence } \\
\text { them }\end{array}$ \\
\hline $\begin{array}{l}\text { Cumulative } \\
\text { experience }\end{array}$ & $\begin{array}{l}\text { Combining the experience of } \\
\text { customers, employees, users, and } \\
\text { a multi-channel environment }\end{array}$ & $\begin{array}{l}\text { The excess of competitors on key } \\
\text { indicators of satisfaction }\end{array}$ \\
\hline $\begin{array}{l}\text { Calculations that } \\
\text { increase privacy }\end{array}$ & $\begin{array}{l}\text { Ensuring the protection of the } \\
\text { data used, maintaining secrecy } \\
\text { and privacy }\end{array}$ & $\begin{array}{l}\text { Need to process data in untested } \\
\text { environments and perform multi-party } \\
\text { data analytics }\end{array}$ \\
\hline \multicolumn{3}{|c|}{ Independence from location } \\
\hline $\begin{array}{l}\text { Distributed } \\
\text { cloud }\end{array}$ & $\begin{array}{l}\text { Using shared cloud services that } \\
\text { are not handled by providers }\end{array}$ & $\begin{array}{l}\text { The solution of technical problems due to } \\
\text { the location of clouds anywhere }\end{array}$ \\
\hline $\begin{array}{l}\text { Ubiquitous } \\
\text { operations }\end{array}$ & $\begin{array}{l}\text { An operating system that supports } \\
\text { customers, employees, and } \\
\text { services from any location }\end{array}$ & $\begin{array}{l}\text { Optimization of mutual contact and } \\
\text { communication between clients and } \\
\text { employees }\end{array}$ \\
\hline $\begin{array}{l}\text { Network cyber } \\
\text { security }\end{array}$ & $\begin{array}{l}\text { Secure access to a digital item } \\
\text { from anywhere in the world }\end{array}$ & $\begin{array}{l}\text { Ensuring the security and availability of } \\
\text { digital services }\end{array}$ \\
\hline \multicolumn{3}{|c|}{ Stable service delivery } \\
\hline $\begin{array}{l}\text { Intelligent } \\
\text { composition } \\
\text { business }\end{array}$ & $\begin{array}{l}\text { Forecasting business processes } \\
\text { based on the analysis of their data }\end{array}$ & $\begin{array}{l}\text { Optimization of the company's activities, } \\
\text { including the decision-making process }\end{array}$ \\
\hline $\begin{array}{l}\text { AI } \\
\text { engineering(AI- } \\
\text { artificial } \\
\text { intelligence) }\end{array}$ & $\begin{array}{l}\text { Optimize the production process } \\
\text { by presenting it in a single clear } \\
\text { way }\end{array}$ & $\begin{array}{l}\text { Increase productivity, scale, reliability, } \\
\text { and return on investment }\end{array}$ \\
\hline $\begin{array}{l}\text { Widespread } \\
\text { automation }\end{array}$ & $\begin{array}{l}\text { Use of effective advanced } \\
\text { technologies and tools }\end{array}$ & $\begin{array}{l}\text { High-quality automation of business } \\
\text { processes, complement of human } \\
\text { potential }\end{array}$ \\
\hline \multicolumn{3}{|c|}{$\begin{array}{c}\text { RESULT: Synergistic effect of digitalization on the company's strategic corporate interests to } \\
\text { achieve sustainable development }\end{array}$} \\
\hline $\begin{array}{l}\text { Intellectual } \\
\text { potential that } \\
\text { unites } \\
\text { employees } \\
\text { through } \\
\text { digitalization }\end{array}$ & $\begin{array}{l}\text { Planning, organizing and } \\
\text { managing employees ' work with } \\
\text { digital technologies based on } \\
\text { corporate culture }\end{array}$ & $\begin{array}{l}\text { Improving the efficiency of the company, } \\
\text { increasing the value of the enterprise, } \\
\text { accelerating the achievement of the } \\
\text { corporate strategy of the company, a new } \\
\text { attitude to employees }\end{array}$ \\
\hline
\end{tabular}

Following these trends will help companies organize a plastic position for development within 5-10 years. The Internet creates an opportunity for" add-ons " of neighborhood interactions to work in teams on projects, successfully implementing a corporate strategy in the context of digital transformation.

Visually, trends can be represented as the formation of corporate efficiency based on a community of practices of people United by common interests through virtual and real space (see Figure 2). 


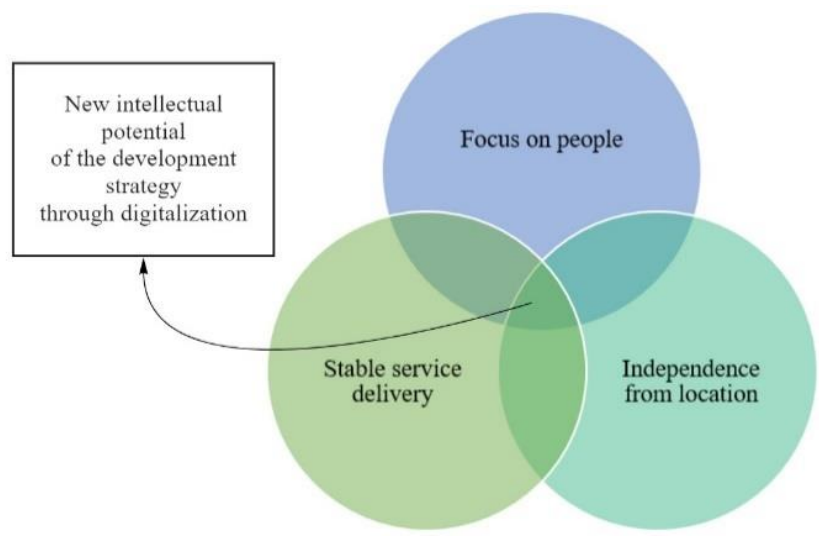

Fig. 2. Current trends in the implementation of corporate strategy in the context of digitalization.

Thus, the successful implementation of a corporate strategy depends on the ability to implement and use all current trends in strategic development as a combination of the power of the Internet and people's intelligence.

\section{Conclusions}

Today, modern companies have the opportunity to develop dynamically through digitalization. The availability of digital technologies allows companies to better meet the needs of consumers, adapt to changes, develop the creative potential of employees and be ahead of the competition.

The corporate strategy directs the organization to the desired result. The desired result changes - the strategy changes. Now the main trigger for changing the desired result is digitalization. Therefore, when implementing digital technologies, companies must train employees in the knowledge and skills of working with digital technologies and improve the corporate culture for effective interaction of technological and human labor. This will allow companies to form corporate strategies for a short period of time, be more flexible to external changes, and increase their competitive advantages.

\section{References}

1. A. G. Chernyshov, Strategy and philosophy of digitalization, Power, 5 (2018)

2. V. G. Khalin, G. V. Chernova, Digitalization and Its impact on the Russian economy and society: advantages, challenges, threats and risks, Management consulting, 10 (2018)

3. S. Blackburn, L. LaBerge, C. O'Toole, J. Schneider, Digital strategy in a time of crisis, McKinseyDigital (2020).

4. E. Y. Dusharina, The Main elements of corporate culture, Economics and business: theory and practice, 3 (2020)

5. M. Rachinger, R. Rauter, C. Müller, W. Vorraber, E. Schirgi, Journal of Manufacturing Technology Management (2018)

6. E. E. Kraus, A. A. Kirakosyan, V. A. Poltavtsev, E. E. Golova, Electronic scientific and methodological journal of Omsk state university, 1 (2018)

7. E. R. Feldman, Strategic Management Review, 1 (2020)

8. N. A. Dosalieva, Problems of modern science and education, 16 (2016) 
9. M. Hitka, M. Vetrakova, Z. Balazova, Z. Danihelova, Business Economics and Management 2015 Conference, 34 (2015)

10. S. Ziyadin, S. Suieubayeva, A. Utegenova, Digital Transformation in Business, Digital Age: Chances, Challenges and Future (2019)

11. Gartner named 9 major technology trends in 2021. Inc. (2020). https://incrussia.ru/

12. K. Panetta, Distributed cloud, AI engineering, cybersecurity mesh and composable business drive some of the top trends for 2021. Gartner (2020). https://www.gartner.com/ 